\title{
A Female with Benign Recurrent Intrahepatic Cholestasis
}

\author{
Ranjit Kumar Banik, Sasanka Kumar Saha, Chanchal Kumar Ghosh, Nikhil Chandra Nath, Helal Uddin, \\ Mohammad Wareshuzzaman, Mohammad Omar Faruk, Swapan Chandra Dhar
}

\begin{abstract}
Benign recurrent intrahepatic cholestasis (BRIC) is a rare autosomal recessive or sporadic disorder, characterized by recurrent episodes of intense pruritus and jaundice that resolve spontaneously without any residual liver damage. Episodic attack can occur at any age but is usually seen at 2nd decade of life. We here report a young female with BRIC who presented the recurrent attack of cholestatic jaundice and pruritus, but was negative for all possible etiology. Liver biopsy was consistent with intrahepatic cholestasis. She was improved after 3 months of suffering from jaundice. On follow-up, she was alright after attack.
\end{abstract}

Keywords: Benign recurrent intrahepatic cholestasis, Pregnancy, Recurrent jaundice.

How to cite this article: Banik RK, Saha SK, Ghosh CK, Nath NC, Uddin H, Wareshuzzaman M, Faruk MO, Dhar SC. A Female with Benign Recurrent Intrahepatic Cholestasis. Euroasian J Hepato-Gastroenterol 2012;2(2):113-115.

Source of support: Nil

Conflict of interest: None

\section{INTRODUCTION}

Benign recurrent intrahepatic cholestasis (BRIC) is a form of relapsing cholestasis that was first reported in $1959 .{ }^{1}$ It is a rare autosomal recessive or sporadic disorder characterized by recurrent episodes of intense pruritus and jaundice that resolve spontaneously without leaving considerable liver damage. The onset of the disease may be at any age. But it usually starts in 2nd decade, $80 \%$ of cases appear before the age of 20. Each attack lasts for a few weeks to months before resolving spontaneously. Patients are completely asymptomatic for months to years between symptomatic periods. The diagnosis can only be confirmed after exclusion of other possible congenital or acquired causes of intrahepatic recurrent cholestasis. ${ }^{2,3}$

\section{CASE REPORT}

A 23-year-old lady presented with recurrent episodes of jaundice and intense pruritus for one and a half years. First attack occurred at March 2010, 8 days after D and C for incomplete abortion at 8 weeks of pregnancy. Jaundice was severe with intense pruritus and was not associated with prodromal features like nausea, anorexia and vomiting or she had no history of abdominal pain and fever. Her stool was pale and bulky. Itching was so severe even she could not sleep at night and it was not relieved by antihistamine drugs. This episode persisted for about 2 months and resolved spontaneously. After that she was well for about next 3 months, she became pregnant for the second time and at 6 weeks spontaneous abortion occurred. After 15 days of abortion she again developed similar type of jaundice and pruritus. This time duration of jaundice was about 2 months and resolved spontaneously.

She again conceived for third time 3 months after the last attack of jaundice. This time her whole gestational period was uneventful and she delivered a female baby at 38th weeks by cesarian section due to premature rupture of membrane. But the baby died of severe pneumonia 4 days after birth. After 15 days of her delivery she again developed jaundice and pruritus and she was admitted in Mitford Hospital, Dhaka, Bangladesh on September 2011. She has no family history of consanguineous marriage. None of her family member suffered from similar type of jaundice. She has history of taking oral contraceptive before she became pregnant. No history of taking other drugs that may cause cholestasis was found. On physical examination she was icteric and she had diffuse excoriation of skin all over the body due to severe itching; her nails were shiny. There was no hepatosplenomegaly or lymphadenopathy. No signs of chronic liver disease. Laboratory investigation revealed hemoglobulin $12 \mathrm{gm} / \mathrm{dl}$, ESR $60 \mathrm{~mm}$ in 1st hour, total white blood cell count $8,000 / \mathrm{mm}^{3}$, platelet count $35,0000 / \mathrm{mm}^{3}$, total bilirubin $17 \mathrm{mg} / \mathrm{dl}$, alanine aminotransferase $32 \mathrm{U} / \mathrm{l}$, alkaline phosphatase $632 \mathrm{U} /$, gamma-glutamyl transpeptidase $30 \mathrm{U} / \mathrm{l}$, prothrombin time 16 seconds (control 12 second), albumin $4.0 \mathrm{gm} / \mathrm{dl}$ and albumin globulin ratio was normal. Hepatitis B surface antigen, anti-HBc IgM, anti-HAV, antiHEV, anti-HCV was not detected in the sera. She was also negative for antimitochondrial antibody, anti-smooth muscle antibody, antinuclear antibody, antiliver kidney microsomal1 antibody, serum ceruloplasmin and alpha-1 antitrypsin level were normal. Ultrasonography revealed normal liver echotexture and normal biliary tree. Bile ducts were normal on magnetic resonance cholangiopancreatography (MRCP). Liver biopsy revealed intracellular and canalicular cholestasis with some ballooning of hepatocytes. Mild inflammatory cells infiltrate in occasional portal tracts and a few foci of parenchymal inflammation were also seen. There was no evidence of portal tract fibrosis or ductopenia. There were no Mallory or Councilman bodies, no siderosis and no steatosis. 
Laboratory and pathology findings made it possible to exclude congenital or acquired causes of intrahepatic and extrahepatic cholestasis and when the relapsing and benign feature of the disease was taken into account a diagnosis of benign recurrent intrahepatic cholestasis was made. DNA analysis was not done due to lack of facilities. In the course of disease ursodeoxycholic acid $300 \mathrm{mg}$ bd, cholestyramine $4 \mathrm{mg}$ tid was started. She was not responding during 1st week of treatment but few days later her symptoms gradually decreased. After about 2 months later she became completely asymptomatic. Liver function test also became normal.

\section{DISCUSSION}

BRIC is an autosomal recessive or sporadic disease that is characterized by intermittent attack of cholestasis. ${ }^{4}$ Each attack can last for several weeks to months. Symptoms free interval can last from several months to years. Liver biopsy is characterized by intrahepatic cholestasis with preservation of normal liver architecture. There is no progression to liver cirrhosis. Although attack seems to be associated with a viral prodrome an inciting viral agent or toxin has not been identified. ${ }^{5}$ Mutation in single gene FICI (recently renamed AT8B1) were found to be responsible for this disease in most families described to date $e^{6,7}$ although genetic heterogeneity is present. ${ }^{8,9}$ Recently BRIC type 2 caused by another mutational change in ABCBII has been documented. ${ }^{10}$

The attacks can start at any age but the first attack usually seen before the second decade of life. In a large series of patient, the age of presentation varied from 1 to 59 years and duration of icteric phase was also variable lasting from weeks to months. ${ }^{1,2,11}$

In our patient first attack was at the age of 22 years. Subsequently two attacks occurred within one and half years of first attack. Each attack lasted about 2 months approximately. Initially she had been diagnosed as infectious hepatitis. But there were no documented causative agent.

In such cases during icteric phase serum bilirubin, bile acids and alkaline phosphatase levels are elevated but gamma-glutamyl transpeptidase was low or normal. Occasionally, ALT and AST levels may be markedly elevated but usually there is only a mild elevation. ${ }^{12}$ In our patient ALT was normal. The clinical presentation, laboratory results and the course of the disease were consistent with the diagnosis of sporadic BRIC. The pathologic findings in her liver biopsy were typical of this entity as well.
To date no effective medical intervention to interrupt the cholestatic attacks in BRIC is available. Several treatment modalities have been described such as cholestyramine and ursodeoxycholic acid. ${ }^{13,14}$ However, this intervention did not have consistent effect on terminating cholestatic attack in our patient. There are some reports that show beneficial role of rifampicin in remission of cholestasis. In our patient, rifampicin was not effective and was stopped 7 days after starting. Patient was on UDCA for 3 months after which patient recovered clinically and biochemically completely. Patients that are not improved with conventional management, partial billous drainage through nasobiliary tube is effective. ${ }^{15}$

\section{REFERENCES}

1. Summerskill WHJ, Walshe JM. Benign recurrent intrahepatic obstructive jaundice. Lancet 1959;2:686-90.

2. Brenard R, Geubel AP, Benhamou JP. Benign recurrent intrahepatic cholestasis: A report of 26 cases. J Clin Gastroenterol 1989;11:546-51.

3. Lidofsky DS. Jaundice. In: Feldman M, Friedman SL, Brandt JL (Eds). Sleisenger and Fordtran's gastrointestinal and Liver disease (8th ed). Philadelphia: Saunders-Elsevier 2006; 1(14):301-16.

4. Bijleveld CM, Vonk RJ, Kuipers F, Havinga R, Fernandes J. Benign recurrent intrahepatic cholestasis: A long-term follow-up study of two patients. Hepatology 1989;9:532-37.

5. Luketic VA, Shiffman ML. Benign recurrent intrahepatic cholestasis. Clin Liver Dis 1999;3:509-28.

6. Van Ooteghem NA, Klomp LW, van Berge-Henegouwen GP, Houwen RH. Benign recurrent intrahepatic cholestasis progressing to progressive familial intrahepatic cholestasis: Low GGT cholestasis is a clinical continuum. J Hepatol 2002;36:439-43.

7. Klomp LWJ, Bull LN, Juijn JA, et al. Characterization of multiple different mutations in FIC1 associated with hereditary cholestasis. Hepatology 1999;30:407A.

8. Sinke RJ, Carlton VE, Juijn JA, Delhaas T, et al. Benign recurrent intrahepatic cholestasis: Evidence of genetic interval between D18569 and D18564. Hum Genet 1997;100:382-87.

9. Floreani A, Molaro M, Mottes M, et al. Autosomal dominant benign recurrent intrahepatic cholestasis (BRIC) Unlinked to 18q21 and 2q24. Am J Med Genet 2000;95:450-53.

10. Luketic VA, Shiffman ML. Benign recurrent intrahepatic cholestasis. Clin Liver Dis 2004;8:133-49.

11. Houwen RHJ, Baharloo S, Blankenship K. Genome screening by searching for shared segments: Mapping a gene for benign recurrent intrahepatic cholestasis. Nature Genet 1994;8:380-86.

12. Nakamuta M, Sakamoto S, Miyata Y, Sato M, Nawata H. Benign recurrent intrahepatic cholestasis: A long-term follow-up. Hepatogastroenterology 1994;41:287-89.

13. Crosignani A, Podda M, Bertolini E, Battezzati PM, Zuin M, Setchell KD. Failure of ursodeoxycholic acid to prevent a cholestatic episode in patient with benign recurrent intrahepatic cholestasis: A study of bile acid metabolism. Hepatology 1991;13:1076-83. 
14. Bircher J. Correspondence: Treatment of patients with benign recurrent intrahepatic cholestasis. Hepatology 1989;10:1030-32.

15. Stapelbroek JM, van Erpecum KJ, Klomp LW, et al. Nasobiliary drainage induces long lasting remission in benign recurrent intrahepatic cholestasis. Hepatology 2006;43:51-53.

\section{ABOUT THE AUTHORS}

\section{Ranjit Kumar Banik (Corresponding Author)}

Assistant Professor, Department of Gastroenterology, Sir Salimullah Medical College and Mitford Hospital, Dhaka, Bangladesh, Phone: 880171 1199659, e-mail: shwapnil@agni.com

\section{Sasanka Kumar Saha}

Assistant Professor, Department of Gastroenterology, Sir Salimullah Medical College and Mitford Hospital, Dhaka, Bangladesh

\section{Chanchal Kumar Ghosh}

Assistant Professor, Department of Gastroenterology, Sir Salimullah Medical College and Mitford Hospital, Dhaka, Bangladesh

\section{Nikhil Chandra Nath}

Assistant Professor, Department of Gastroenterology, Sir Salimullah Medical College and Mitford Hospital, Dhaka, Bangladesh

\section{Helal Uddin}

Registrar, Department of Gastroenterology, Sir Salimullah Medical College and Mitford Hospital, Dhaka, Bangladesh

\section{Mohammad Wareshuzzaman}

Assistant Registrar, Department of Gastroenterology, Sir Salimullah Medical College and Mitford Hospital, Dhaka, Bangladesh

\section{Mohammad Omar Faruk}

Associate Professor, Department of Gastroenterology, Sir Salimullah Medical College and Mitford Hospital, Dhaka, Bangladesh

\section{Swapan Chandra Dhar}

Professor, Department of Gastroenterology, Sir Salimullah Medical College and Mitford Hospital, Dhaka, Bangladesh 